\title{
THE CONCEPT OF TOLERANCE AFTER SYRIAN REFUGEE FLOW IN TURKEY
}

\author{
Hüseyin HAYDARI'* \\ ORCID ID: 0000-0003-3043-0119
}

\begin{abstract}
Migration is a phenomenon that has been on the agenda in Turkey throughout history. Refugees and migrants' issues, which are extremely strong, multidimensional, and complex, should be widely investigated. At this point, this investigation has been advanced to analyze the connection between the idea of tolerance and the expanding number of refugees in Turkey. Therefore, the aim of the study is to see the change in the level of tolerance towards migrants in Turkey after the Syrian asylum seeker influx. The data provided by the content analysis method conducted on the Twitter social media platform by using specific keywords with covering the years 2012, 2015, and 2018, were analyzed in harmony with the literature review. However, the reliability of the study was tried to be ensured by the inter-judge reliability method. The findings indicate a decrease in the tolerance level in Turkey towards the migrants after Syrian asylum seekers' arrival.
\end{abstract}

Keywords: Syrian Refugee, Tolerance, Turkish Society, Migration.

* PhD(c), Researcher, Nişantaşı University, Finance, Economic and Policy Research Application and Research Center, hsyn.haydari@gmail.com

DOI: https://doi.org/10.53662/esamdergisi.898811 


\section{SURIYELİ MÜLTECI GÖÇÜNDEN SONRA TÜRKIYY'DEKİ HOŞGÖRÜ KAVRAMI}

Öz: Göç olgusu, kapsamı ve niteliği itibariyle Türk siyasal hayatına etki eden bir fenomen olma özelliğine sahiptir. Çok boyutlu araştırmaları gerektiren karmaşık doğasının odak noktasında özelde mültecilere genelde tüm göçmenlere dönük yaklaşımlar yer almaktadır. Bu araştırma, Türk kültürünün temel unsurları arasında kabul edilen "hoşgörü” olgusunun 2012 sonrası dönemde mültecilerin sayısındaki artış sonrasında yaşadığı değişimi/dönüşümü "İstisna Durumu” teorisi kapsamında analiz etmek için geliştirilmiştir. Çalışmanın amacı, Suriyeli sığınmacı akını sonrasında Türkiye'deki göçmenlere yönelik hoşgörü düzeyindeki değişimi incelemektir. Bu bağlamda, önceki anket çalışmalarından elde edilen veriler, literatür ile birlikte incelenmiş ve analiz edilerek çalışmanın kapsamı noktasında dahil edilmiştir. Twitter sosyal medya platformunda belirli anahtar kelimeler kullanılarak 2012, 2015 ve 2018 yıllarını kapsayan içerik analizi yönteminin sağladığı veriler analiz edilmiştir. Bu noktada çalışmanın başat veri sağlama yöntemi olan içerik analizinin güvenilirliğini sağlamak adına gözlemciler arası güvenilirlik metodu uygulanmıştır. Temel bulgular, Suriyeli sı̆̆ınmacıların gelişinden sonra Türkiye'deki göçmenlere yönelik hoşgörü düzeyinde bir düşüşe işaret etmektedir.

Anahtar Kelimeler: Suriyeli Mülteci, Hoşgörü, Türkiye Toplumu, Göç.

\section{INTRODUCTION}

Migrants and refugees' ${ }^{1}$ issues, which are very powerful, multidimensional, and complex, ought to be extensively researched. At this juncture, this study has been put forward to examine the relationship between the concept of tolerance, which is one of the basic spiritual building blocks of Turkish society, and the increasing number of refugees in Turkey in recent years. However, a number of deficiencies and changes have been observed in the tolerance of society, especially in the last few years. The number of Syrian refugees in particular has reached uncontrollable dimensions especially during the refugee influx after the Arab Spring. The Syrian refugees have been placed in tent cities and camps in the South-eastern Anatolia region after influx. However, due to the

\footnotetext{
${ }^{1}$ In this article, the concept of 'refugee' was chosen for the Syrians asylum seekers in Turkey.
} 
incapability of camps and tent cities, and also lack of economic opportunities, a large part of people headed and settled in the surrounding cities.

Actually migration is a phenomenon that has been experienced in Turkey since $19^{\text {th }}$ century. ${ }^{2}$ After the Ottoman Empire lost its lands in the Balkans, Crimea and Caucasus, the Turkish people who lived there for centuries have flowed to the Anatolian lands. ${ }^{3}$ After the disappearance of the Ottoman Empire at the end of the First World War, many people of Turkish origin remained outside the borders of the Republic of Turkey. In this sense, the modern Republic of Turkey has accepted a large number of immigrants, mainly ethnic Turkish immigrants. ${ }^{4}$ After the population exchange with Greece and Bulgaria, with the Law of Settlement issued in 1934, it was decided to accept, settle and grant citizenship of immigrants of ethnic Turkish origin and living in Turkish culture. ${ }^{5}$ At different times during the modern Turkish history, the number of immigrants from Bulgaria, Iraq, and the Balkans to Turkey was quite large. ${ }^{7}$ In this sense, the Republic of Turkey, which is familiar with such phenomena as mass migration and refugee influx, has hosted the largest influx of refugees since WW2 in the history of the world with the Syrian crisis. ${ }^{8}$

Firstly, literature review has been done in order to find former related studies' findings and to explore their methods. Later on, social media platform Twitter was investigated to examine changing perception towards Syrian refugees in specific periods of times. Keyword-based content analysis method was conducted on twitter messages that containing specific words ${ }^{9}$ and were examined specifically for 2012, 2015 and 2018. All tweets posted in those three years and contain the key words are examined. Then classification criteria of those tweets are determined in accordance with the opinions of experts. According to experts, there would be six sub-classifications under the basic 'positive-negative-neutral' classification. Those sub-classifications are as

\footnotetext{
2 Arzu Çalışkan Sarı; Özden Yalçınkaya Alkar. "The Attitudes towards Syrians Living in Turkey: A Scale Development”, Göç Araştırmaları Dergisi 4/2 (2018), 13.

3 Filiz Çolak, "Bulgaristan Türklerinin Türkiye’ye Göç Hareketi”. Tarih Okulu Dergisi, 14, (2013) 122.

4 Kemal Kirişçi, Misafirliğin Ötesine Geçerken Türkiye’nin "Suriyeli Mülteciler” Sinavı Raporu. (Uluslararası Stratejik Araştırmalar Kurumu \& Brookings Enstitüsü, 2014).

5 Kemal Kirişçi, "Refugees of Turkish origin: "Coerced immigrants" to Turkey since 1945” International Migration 34/3, (1996). 392.

6 Mehmet Pınar, “1950-1951 Bulgaristan’dan Türkiye’ye Göçler ve Demokrat Parti’nin Göçmen Politikası”, Atatürk Araştırma Merkezi Dergisi 30/89 (2017), 84.

7 Çolak, “Bulgaristan Türklerinin Türkiye’ye Göç Hareketi”, 129

8 Kemal Kirişci, "Turkey's Role in the Syrian Refugee Crisis: An Interview with Kemal Kirişci". Georgetown Journal of International Affairs (2016), 82.

9 Suriyeliler (Syrians), Mülteciler (Syrian Refugees), Suriyeli göçmen (Syrian Migrant)
} 
follows; 'News and Information posts', 'Politicians' Posts', 'Personal Independent Opinion Posts', 'Tolerance, Sensitive and Humanitarian Posts', 'Posts in the Nature of Aid and Social Responsibility' and 'Hate and Depreciatory Posts'. The numerical multiplicity of the posts in each group, the ratio of these data to total twitter users in Turkey, and the increment or decrement of the number of posts in specific classification group by years were determined as the primary examination criteria. On the other hand, this is worth to say that, the tweet posts that are part of any flood are considered by their general meaning in the post floods. Another point that should be mentioned is the content of the shares classified in the category of independent personal opinions. In this category, we see the shares that are neither positive nor negative towards Syrian refugees. So, shares addressed to the government over money spent on refugees, comparisons between Turkey and foreign countries in terms of the number of refugees admitted to the country, shares of images showing the status of Syrians in Turkey, which might call neutral, or those who share their personal memories of them has counted in the category of Personal Independent Opinion Posts. In addition, within the scope of the literature review, changes in attitudes towards refugees over time were also examined by comparing the results of previous surveys on different dates. In the light of this, the data obtained from both methods were analysed and a concrete result revealed. Based on these findings, the evaluation, conclusions and recommendations section is just located at the end of the study.

Descriptive content analysis is a systematically review that aims to identify and describe the general trends and research results in a particular research discipline. ${ }^{10}$ Furthermore, the content analysis method is meant to produce sheer amount of data source for practitioners, researchers, and policymakers to aid in the identification of potential future research fields. This method is summaries of studies and ingredients that aid in the dissemination of research findings as well as the influencing of future research, policy, practice, and public perception. ${ }^{11}$

The reliability of this study has tried to be provided by choosing the keywords and the research years based on 3 each. In other words, the results of each content analysis performed with the keywords were compared with each other, making sure that there was a meaningful relationship between them. However, the reliability of the study tried to be ensured by the inter-judge reliability method. In accordance with this method, there are different researchers categorized the findings of the same keywords

\footnotetext{
10 Muammer Çalık, et al. "Trends in Turkish Science Education”. Essays in Education 24/1, (2008) 4.

${ }^{11}$ Harsh Suri, David Clarke, "Advancements in Research Synthesis Methods: From A Methodologically Inclusive Perspective”. Review Of Educational Research 79/1, (2009), 395-430
} 
and the same years. ${ }^{12}$ At this point, we encountered a result that would confirm the results of this study, except for minor differences that would not affect the nature of the study in the grouping of tweets posted. The coefficient of correlation of results is 0,79 , 0,84 , and 0,96. In addition, another reliability analysis of the scale is a test-retest method. After the second application of anylsis method three weeks apart, the reliability correlation coefficient obtained between the applications was determined as $r=0,82$. This finding is also proof that the reliability determined by the scale is high.

The research question of this study is 'How Turkish society's tolerance and hospitality towards Syrian refugees change over time from 2012-2018?' Also the critical markers of the change in the level of tolerance of Turkish society towards Syrian refugees mentioned in context of this research study. According to research question, first hypothesis of this study is 'The level of tolerance in Turkish society has changed over time after Syrian refugee flow', the second hypothesis of this study is 'The level of tolerance in Turkish society has not changed over time after Syrian refugee flow'. In addition, hate speech, which is one of the key elements that trigger intolerance in society, will constitute one of the important elements of this study. Then, a number of recommendations will be made as a result of the research. In particular, these recommendations, which will accelerate the integration of Syrian refugees into Turkish society and provide an environment conducive to mutual exchange of benefits, will be formed as a result of literature surveys and keyword-based content analysis on Twitter. Thanks to the above recommendations, the integration of refugees into the society will be accelerated and their benefit to the society will increase. Thus, refugees will become individuals who would contribute to the development of the Republic of Turkey rather than being a problem.

In this context, the theoretical background of this study is based on Schmitt's theory of 'State of Exception'. In this sense, hosting an influx of refugees exceeding 3.6 million (UNCHR) and meeting all the basic needs of these people is not an easy process. From this point of view, we can say that the Republic of Turkey was a state that has no related legal regulations about Syrian refugees in 2011, but then government started to form all the new legal regulations that the situation requires over time by acting in accordance with the theory of 'the State of Exception' in order to get out of this crisis. Refugee influx started in 2011 but the first legal regulation has been put forward in 2013. The fact that the Turkish government establish rapid legal arrangements ${ }^{13}$ by using its political power to provide opportunities towards Syrian

\footnotetext{
12 Kaan Böke. Sosyal Bilimlerde Araştırma Yöntemleri (İstanbul: Alfa Yayınları, 2014), 95-96.

${ }^{13}$ Also see; Foreigners And International Protection Law in 2013

Temporary Protection Regulation in 2014

Regulation on Work Permits of Foreigners Provided Provisional Protection in 2016
} 
refugees such as implementation of open door policy, building tent cities, providing education and health facilities and financial support has a major role in the relative recovery of the crisis. In addition, when examining the change in the level of tolerance towards the Syrian refugees in the Turkish society within the scope of the study, as a macro-level analysis of society, we see that the conflict between the two communities has come to the agenda especially in the recent period. At this point, we can say that Marx's theory of conflict into the society is suitable for this study. More precisely, one of the main reasons for the recent tension between the two communities is the conflict in the nature of society.

\section{MAIN REMARKS ON THE ISSUE}

There are some literature studies and questionnaires related to the subject in the literature. The most important of these is the understanding of tolerance in society, factors affecting social tolerance, attitude and perception of Turkish people towards foreigners and immigrants, rising hate speech and depreciation in society, the problems of Syrian refugees in Turkey, and local communities' reactions against Syrian refugees.

Tolerance means indulgence, folding, ignoring or turning a blind eye to simple mistakes, laissez faire others in their actions and judgments, put up with patiently and without taking someone's side. ${ }^{14}$ It is also used in terms of disregard, behaving well and allowing. In social relations, it is a situation such as a person does not react to the counterparty in a material-moral detrimental situation that is revealed by unwittingly, unintentionally and unconsciously. ${ }^{15}$ The concept of tolerance is the act of purposely avoiding intervention against people whose beliefs, values and behaviour are different in society, even if their actions are not approved. ${ }^{16}$ Tolerance takes place in various forms in social life ${ }^{17}$ : the approach with understanding of those who are socially different from us is called 'social tolerance'; approach with understanding to those who are religiously different is called 'religious tolerance'; approach with understanding to those who have different political beliefs and thoughts is called 'political tolerance'; approach with understanding to those who have different cultures is called 'cultural

\footnotetext{
14 Ömer Aslan. "Hoşgörü ve Tolerans Kavramlarına Etimolojik Açıdan Analitik Bir Yaklaşım”. Cumhuriyet Üniversitesi İlahiyat Fakültesi Dergisi 5/2 (2001), 357-380.

15 Şafak Kaypak, "Demokrasi Kültürü ve Hoşgörü: Hatay Örneğinde”, 2. Uluslararası Çin'den Adriyatik’e Sosyal Bilimler Kongre Kitabı. (2016), 94.

${ }^{16}$ Andrew Jason Cohen, "What toleration is". The Journal of Ethics 115 (2004). 68-95.

17 Mehmet Sağlam, “Geleneksel Türk Hoşgörüsü”. Erdem Dergisi 8/23 (1996), 359-364.
} 
tolerance; approach to those who have different level of income is called as 'economic tolerance'. ${ }^{18}$

The word 'hate' is defined by Demirtas as demanding a person's evil and unhappiness, and feeling disgust from the person. ${ }^{19}$ Hate, which is a powerful and destructive feeling, occurs in situations such as unacceptable situations, unresolved problems and unresolved needs. According to Çayır, a person who does not like spinach may have a feeling of hatred even when stating that he hates spinach. ${ }^{20}$ Hate, however, can merge with ideology, and hatred can transcend individuals and turn toward everyone in opposing ideologies. According to Çayır, when hate is part of an identity, that identity cannot define itself independently of the hated group. ${ }^{21}$ Discrimination forms such as prejudices, racism, fear-hostility of 'strangers', sexism and homophobia lie at the basis of hate speech and discriminatory discourse. Factors such as cultural identities and group characteristics influence the frequency of the use of marginalizing and aggressive discourses. Especially in the contexts where nationalism is strengthened and intolerance to the differences increases, the effect of hate language is intensified.

Actually, investigations into Syrian refugees generally appear to have intensified in 2014. In other words, before 2013, the number of refugees were not seen as a significant number for investigation. ${ }^{22}$ Despite many impacts and risks directly reflected in the daily life of the Turkish population by Syrian refugees living in Turkey for 3 years with exceeding 1.5 million as of November 2014, especially the study that has been conducted by Murat Erdogan in 2014 reflects that Turkish society shows significant social acceptance towards Syrian refugees. Erdogan continued his studies in this area and according to his study in 2017, despite some unrest; he highlighted the high social acceptance and internalization shown by Turkish society. ${ }^{23}$ Humanitarian emphasis comes to the forefront with $64.6 \%$ as the reason for the social acceptance of the Turkish people in the literature. ${ }^{24}$ In accordance with Erdogan's study, Tamer has

\footnotetext{
18 Mustafa Erkal, “Sosyal Bütünleşmede Hoşgörünün Yeri”, Erdem Dergisi 8 (1992), 154.

19 Timur Demirbas, "Nefret Söylemi ve Nefret Suçları". Dokuz Eylül Üniversitesi Hukuk Fakültesi Dergisi 19/3 (2017). 2693-2701.

20 Kenan Çayır, “Ayrımcılığın sosyolojisi ve Türkiye toplumu”, Nefret Suçlarl ve Nefret Söylemi, Ed. Ayşe Çavdar and Aylin B. Yıldırım (İstanbul: Uluslararası Hrant Dink Vakfı Yayınları. 2010), 48.

${ }^{21}$ Hasan Karaman and Şevki Işıklı, "Twitter'daki Dini ve Etnik Temelli Nefret Söylemlerinin Analizi”. AJIT-e: Online Academic Journal of Information Technology 7/25. (2016), 146.

22 Sinem Yıldırımalp \& İyem Cemal "Suriyeli Sı̆̆ınmacıların Toplumsal Kabul ve Uyum Sürecine İlişkin Bir Araştırma". Bilgi Sosyal Bilimler Dergisi 2 (2017), 117.

23 Murat Erdoğan, Türkiye'deki Suriyeliler: Toplumsal Kabul ve Uyum Araştırmast. (Hacettepe Üniversitesi Göç ve Siyaset Araştırmaları Merkezi, 2014), 164.

24 Erdoğan, Türkiye'deki Suriyeliler, 165.
} 
published a study in 2016 which was done in Trabzon, city of Turkey, for measure the local community's perception about Syrian refugees. In this context, her survey study demonstrates that, it turns out that the level of public acceptance of Syrians in Trabzon is extremely high. ${ }^{25}$ But in addition, thoughts such as no longer accepting new asylum seekers, sheltering Syrians in camps or sheltering them there by creating a buffer zone on Syrian territory along the border are quite common in Trabzon public opinion. ${ }^{26}$

In the study, called as "Demokrasi Kültürü ve Hoşgörü: Hatay Örneğinde" published in 2016, Kaypak combined the concepts of democracy culture and tolerance, and conducted a specific study on this issue in Hatay, a city in Turkey. According to his findings, people of different languages, religions and ethnicities in Hatay have lived side by side for centuries without disturbing each other and have tolerated and respected each other's lifestyles. Besides, his claims, which later turned out to be unfounded, were grounded the idea that it could continue to maintain this structure even if the city encounters an influx of Syrian refugees. Karaman and Işıklı painted a black picture about hate speech in society in their article which is called as "Analysis of Religious and Ethnically Based Hate Speech on Twitter" and published in 2016. So, they focused to the forms of pruduction of hate speech in social media, specifically in Twitter. According to their study, the reasons for this black picture are the fact that the problems from the past such as the Armenian genocide allegations, the unsolved Kurdish and the Alevi problem. Alongside the mentioned reasons, the fact that Democratic reflexes of society still have many aspects to improve, factors such as intolerance to differences, state policies, and media inciting discrimination are also some important elements that affect the negative picture. According to Vardal, who conducted research on social media channels in 2015; new media supports the spread of hate speech while having a relatively democratic appearance with user content structure, legitimized by the manufacturer-users cause. Öztekin, on the other hand, carried out his study on hate speech through the 'Ekşi Sözlük' in 2015 and put forward the following opinion on new media; the characteristics of the new media replace it in a privileged and superior position in the face of the traditional media, while allowing the widespread and unsupervised production of hate speech. In a study conducted in 2015, Kurt deals with YouTube videos containing hate speech towards Syrian refugees and the related videos are analysed by Van Dijk's critical discourse analysis method. In his study, he demonstrates that hate speech needs to be taken seriously and suppressed and taken precautions while it is still in the dimension of attitude, behavior and discourse. In this

\footnotetext{
25 Mine Gözübüyük Tamer, "Trabzon Kamuoyunun Geçici Koruma Kapsamındaki Suriyelilere Bakış Açısı" Karadeniz Araştırmaları Enstitüsü Dergisi 2/2 (2016), 202.

26 Tamer, “Trabzon Kamuoyunun Geçici Koruma Kapsamındaki Suriyelilere Bakış Açısı”, 203.
} 
sense, various measures and regulations need to be taken to suppress hate speech in social media. ${ }^{27} \mathrm{~s}$

According to Murat Erdogan's study published in 2019, in the Republic of Turkey, which had only 58 thousand refugees in 2011, the fact that people had to live with more than 4.1 million refugees after 2011 could be said to cause a significant 'social shock'. However, it must be acknowledged that the level of social acceptance of Turkish society is still extremely high despite all its concerns, the social shock, the tendency of discomfort and rejection, and the Turkish society's desire of Syrians to turn back to their country. The performance, solidarity and acceptance of the Turkish community in this regard are extremely valuable. ${ }^{28}$ Another study to support this thesis is the results of the field research conducted by Güçer, Karaca and Dinçer in May 2013. Within the scope of this research, $42 \%$ of the answers given to the question of 'How satisfied the refugees with the local people' in the interviews with the refugees staying in the camps were evaluated as full points (10 points between $0-10$ ). In addition, $83.3 \%$ of the participants scored as good and above. ${ }^{29}$ However, according to the study conducted by Dinçer et.al. in 2013, despite some periodic tensions, the selfless and benevolent stance of the Turkish people since the onset of the Syrian refugee crisis until 2013 was particularly made the Syrian refugees pleasing. In fact, in interviews conducted within the framework of Dinçer et.al.'s research, the words made by a refugee demonstrate the situation more clearly: 'when we are in Turkey, we feel like we are in our homes' ${ }^{30}$ However, it did not raise a problem between the two communities unless the Turkish community reflects their anxious, pessimistic and uneasy feelings on Syrian refugees, along with the phenomenon of 'unwillingness' or 'reluctantly acceptance'. According to the results of the field study conducted by Çimen and Quadir in 2018 on Turkish university students, the participants did not agree with the negative thoughts about Syrians, but these participants were undecided about defending the rights of Syrian refugees and providing in kind and cash assistance to the refugees. That is to say, Turkish society show a certain degree of social acceptance, but still expresses that they are not very satisfied with this advanced situation of hospitality.

27 Gözde Kurt, "Yeni medyada nefret söylemi: YouTube'da Suriyeli mültecilere karşı üretilen nefret söylemi üzerine bir araştırma" The Journal of International Lingual Social and Educational Sciences 5/1 (2019), 15.

${ }^{28}$ Murat Erdoğan, Türkiyedeki Suriyeli Mülteciler (Konrad Adenauer Stiftung, 2019).

${ }^{29}$ Mehmet Güçer et al., Sınırlar Arasında Yaşam Savaşı Suriyeli Mülteciler Alan Çalışması. (International Strategic Research Organization-USAK, 2013), 43.

${ }^{30}$ Osman Bahadır Dinçer et al., Suriyeli mülteciler ve Türkiye: Sonu gelmeyen misafirlik. International Strategic Research Organization and Brookings Enstitüsü, (Ankara: Karınca Ajans Yayıncıllk Matbaac1l1k, 2013). 
In fact, as inferred from Figure 1, according to a survey conducted by the World Values Survey in 2012, 61.4\% of the Turkish people see the sense of 'tolerance and respect for other people' as one of the most important issues in children's education, but reversely they can take the opposite stance when it comes to migrants and refugees. According to the results of a survey conducted in 2012, 38\% of the world's population was identified as anti-immigrant, while the anti-immigrant population in Turkish society was found to be around $61 \% .{ }^{31}$ According to the results of a 2013 study by the German Marshall Fund, we can see that Turkish people are divided into two very close groups, with $46 \%$ stating that immigrants pose problems and $45 \%$ stating otherwise. ${ }^{32}$ The results of the same survey show that $66 \%$ of Turkish people are against legal immigration. In another survey conducted by the same organization in 2014 its shown that the Turkish people's view that 'migrants are a problem' was soared to 75\%, which is $29 \%$ higher than the previous year, and this could be interpreted as a result of the increasing number of Syrian refugees in Turkey. ${ }^{33}$ Though, the results of the Twitter analysis conducted within the scope of this study are supported by the data obtained from the above-shared literature.

Figure 1: Proposition $=$ Important child qualities: tolerance and respect for other people

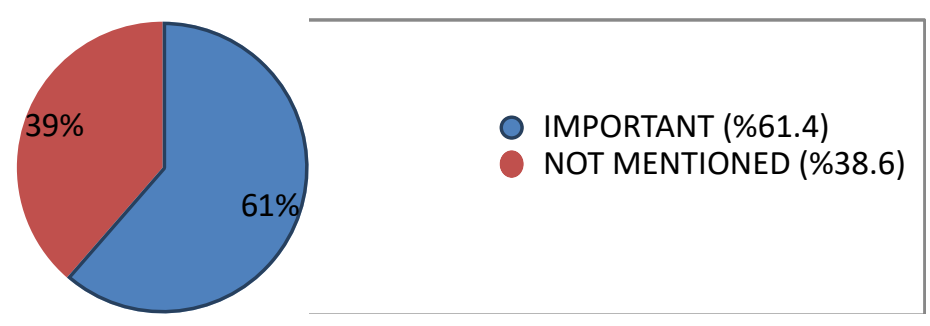

Source: Selected sample: World Values Survey, Turkey 2012 (1605)

According to data that shown in table 1, which dates to 2012, as shown below with the chart, $30.5 \%$ of the Turkish people do not prefer a foreigner or immigrant neighbour.

\footnotetext{
${ }^{31}$ Serdar Ünal, "Türkiye'nin Beklenmedik Konukları: 'Öteki' Bağlamında Yabancı Göçmen ve Mülteci deneyimi" Zeitschrift für die Welt der Türken/Journal of World of Turks 6 (2014), 73.

32 The German Marshall Fund of United States (GMF), Transatlantic Trends Key Findings 2013. (New York: The German Marshall Fund of United States, 2013).

33 The German Marshall Fund of United States (GMF), Transatlantic Trends: Mobility, Migration And Integration. (New York: The German Marshall Fund of United States. 2014).
} 
Table 1: Proposition = Could you please mention any that you would not like to have as neighbours; immigrants-foreign workers?

\begin{tabular}{|c|c|c|}
\hline & Number of cases & \% Total \\
\hline Mentioned & 490 & $30.5 \%$ \\
\hline Not mentioned & 1,115 & $69.5 \%$ \\
\hline$(\mathrm{N})$ & $(1,605)$ & $100 \%$ \\
\hline
\end{tabular}

Source: Selected sample: World Values Survey, Turkey 2012 (1605)

The data of another research company, 'Türkiye Sosyal-Siyasal Eğilimler Araştırmas1', aiming to measure the satisfaction of Syrian migrants compares 2016 with 2018.34 In this study, it is observed that the rate of dissatisfaction increases from 2016 to 2018. 12\% of respondents, who took a neutral stance in 2016, expressed different opinions in 2018. Approximately $10 \%$ of this $12 \%$ change their expressions in the direction of dissatisfaction. According to the years, we can see that the satisfaction of the Turkish people with foreigners and immigrants has dropped significantly.

Figure 2: To what extent are you satisfied with the Syrian migrants in our country?

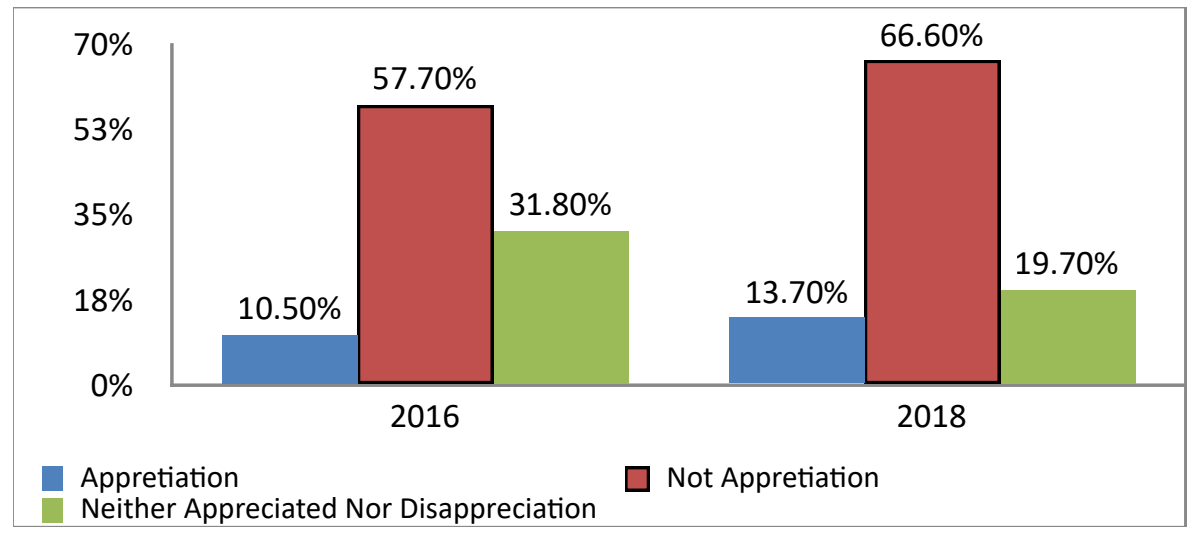

Source: Türkiye Sosyal-Siyasal Eğilimler Araştırması 2018

At this point, the following result emerges: 2013 and 2014 are a period in which the Turkish people's view of migrants due to Syrian refugees has changed. ${ }^{35}$ As Erdogan mentioned in his book Syrians Barometer published in 2018, Turkish society still defines Syrians as victims of war. However, the following definitions show some changes; 'people who are a burden to us', 'people likely to cause problems', 'beggars /

\footnotetext{
34 Mustafa Aydın. et al., Turkiye Sosyal Siyasal Egilimler Arastirmasi 2018, (Kadir Has Üniversitesi, 2018). 66

35 GMF, Transatlantic Trends Key Findings 2013.
} 
people living only with help', and 'people quite different from us and unfamiliar to us'. ${ }^{36}$ This reveals both the anxiety and widespread otherness that emerged in Turkish society after 2014. In another study of Erdogan that published in 2020, its revealed that the adaptation of Syrians to Turkish society is quaite scanty. As we see in the figure 3 in below, almost half of the Turkish society perceive that Syrians are not adopted to Turkey. Totally, \%64 of respondants share their negative views about Syrians integration to Turkish society.

\section{To What Extent Have Syrians Adapted To Turkish Society/Turkey?}

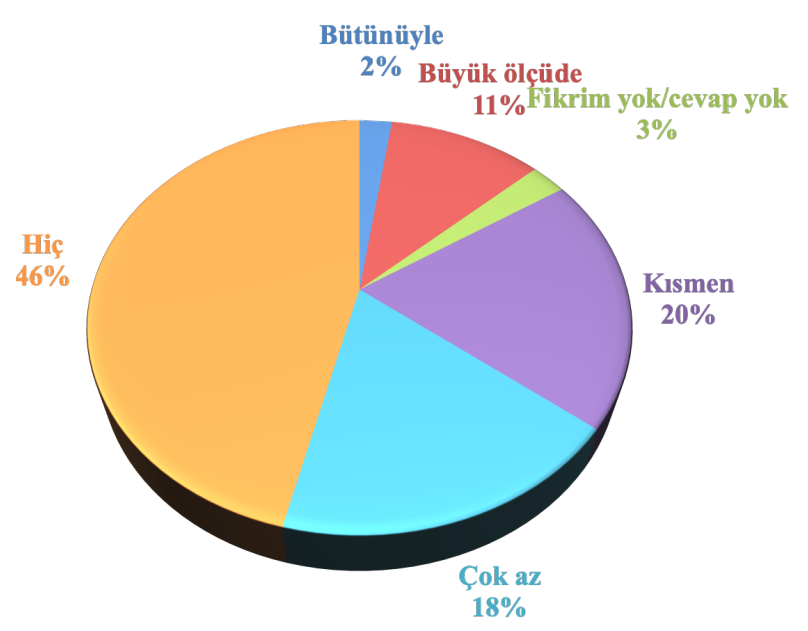

Figure 2: To what extent have Syrians adapted to Turkish society/Turkey?

Source: Erdogan, M. 2020. Suriyeliler Barometresi 2019, UNHCR

A study supporting this thesis was also conducted by Çiftçi in 2018. According to the results of the study, the Turkish people's perspective on Syrians has changed considerably from 2011 until 2018 (2252). In other words, we can see that Turkish society has evolved in different directions by abandoning its hospitable-based stance in 2011. The main reasons for this situation, according to this study, include the lack of clarifying the status and stay of Syrian refugees and the problem of whether they should be granted citizenship. According to the results of a study conducted by Çimen and Quadir in 2018, the main reasons for this negative attitude and perception that emerged in the post-2014 period in the Turkish people are the prolonged and uncertain process and many adversities. As Kaya stated in her 2015 study, migration will become a multidimensional social network, both for Turkish people and for refugees, as the length of Syrian refugees' stay gets longer. In this context, it is envisaged in this study that an environment suitable for the emergence of social conflict will occur (278). According to

36 Murat Erdoğan, Suriyeliler Barometresi: Suriyelilerle Uyum Iç̧inde Yaşamın Çerçevesi (İstanbul: İstanbul Bilgi Üniversitesi Yayınları, 2018), 164-165. 
the results of a field survey conducted in Istanbul, which attempts to measure changing attitudes and perceptions towards Syrians, the proportion of respondents who answered to the question 'Do you think the presence of foreigners is good for your city' as 'I strongly disagree' was $14.8 \%$ before the arrival of Syrian refugees in 2009 , compared to $34 \%$ after the increased number of Syrian refugees in $2015 .{ }^{37}$ With these results, we see that the Turkish people entered into negative attitudes and perceptions towards the Syrian refugees, especially after 2014. In addition, another element mentioned in the literature is the unrest caused by the fact that the Syrian refugees lives outside the camp, and therefore they are intertwined with those of the Turkish people. The fact that refugees are li ving in cities is increasingly influencing the social, political and economic life of Turkish society. ${ }^{38}$ It is a remarkable finding at this point that the level of identification of Syrians in Turkish society as 'our brothers of religion' or 'some of us' is almost non-existent. ${ }^{39}$ At this point, it can be said that the 'solidarity myth', which politicians try to create with the emphasis of 'Ansar-Muhajir'40 that stems from the reference and emphasis on the event of the emigration in Islamic discourse, has found a very limited response on the basis of society. ${ }^{41}$

In the light of the above matters, operationalization of the terms that has been used in this study is determined according to literature review. There are two main terms that needed to be operationalized; Refugee, Hate and Tolerance. The word refugee has been determined to use by its meaning retrieved from United Nations High Commissioner for Refugees (UNHCR); people who have fled war, violence, conflict or persecution and have crossed an international border to find safety in another country. 42 Operationalization of the sense of hate is as demanding a person's evil and unhappiness, and feeling disgust from the person. On the other hand, the operationalized meaning of tolerance is already mentioned above and retrieved from Turkish Language Association; indulgence, folding, ignoring or turning a blind eye to simple mistakes,

\footnotetext{
37 Ayşegül Taşöz Düşündere and Yasemin Satır Çilingir, Göçmenlere karşı kötümserlik artıyor mu? (Türkiye Ekonomi Politikaları Araştırma Vakfı 2017).

38 Dinçer et. al., Suriyeli Mülteciler ve Türkiye, 27.

${ }^{39}$ Erdoğan, Suriyeliler Barometresi, 164.

40 In the Islamic literature, the concept of emigrants is the name given to people in a society who escaped from persecution in any region and took refuge in another community, while the concept of Ansar is the one that protects these refugees.

${ }^{41}$ Erdoğan, Suriyeliler Barometresi, 165.

42 United Nations High Commissioner for Refugees (UNHCR), "What is A Refugee". (Access: 20.11.2020).
} 
laissez faire others in their actions and judgments, put up with patient and without taking someone's side. ${ }^{43}$

On the other hand, the theoretical background of this study is based on Schmitt's theory of 'the State of Exception'. ${ }^{44}$ In this sense, hosting an influx of refugees exceeding 3.6 million and meeting all the basic needs of these people is not an easy process. From this point of view, we can say that the Republic of Turkey was a state that has no related legal regulations about Syrian refugees in 2011, but then government started to form all the new legal regulations that the situation requires over time by acting in accordance with the theory of 'the State of Exception' in order to get out of this crisis. ${ }^{45}$ Refugee influx started in 2011 but the first legal regulation has been put forward in 2013. The fact that the Turkish government establish rapid legal arrangements by using its political power to provide opportunities towards Syrian refugees such as implementation of open door policy, building tent cities, providing education and health facilities and financial support has a major role in the relative recovery of the crisis.

\section{TWITTER ANALYSIS FINDINGS}

Firstly, Twitter, which is one of the largest social media channels and used for social organization, mass communication, and sharing of personal feelings, thoughts, and opinions, has been used quite widely in the world and in Turkey in the last 10 years. According to 2012 data, Twitter has 7.2 million unique users in Turkey. 5.3 million Twitter's Turkey-based users in 2012 actively used Twitter. ${ }^{46}$ In 2012, 1.7 million Turkish tweets were published per day. By the end of 2014, in Turkey, the market research firm GlobalWebIndex reported that there are 11.5 million user accounts and 5.6 million active active users in Twitter. ${ }^{47}$ According to a report released in October 2018, 8.8 million people in Turkey actively use Twitter. ${ }^{48}$ But active users in 2018 are estimated to be around 8.33 million. From all this information, the following sections

\footnotetext{
43 Kaypak, Demokrasi Kültürü ve Hoşgörü, 150.

44 Ömer Faruk Gök, “Schmitt ve Benjamin: İki Olağanüstü Hâl”. Hukuk Kuramı Dergisi, 4/3. (2017).

45 Georgio Agamben, Kutsal Insan: Egemen İktidar ve Çıplak Hayat. (Ayrıntı Yayınları, 2001); Marie Goupy, "The State Of Exception Theory of Carl Schmitt And The Ambivalent Criticism of Liberalism", Zeitschrift für Politikwissenschaft 28/4 (2018), 399.

46 Ahmet Can Şit, “Türkiye saniyede 20 tweet atıor”, Webrazzi (Access: 12.12.2020).

47 Digitalage, “Twitter'1n 2014 Türkiye Karnesi”, (Access: 13.11.2020)

48 Sabah, 19.3.2018: https://www.sabah.com.tr/teknoloji/2018/03/19/dunyada-3-milyar-190-bin-kisisosyal-medya-kullaniyor ; Milliyet, 19.10.2018: http://www.milliyet.com.tr/teknoloji/turkiyenin-sosyalmedya-karnesi-aciklandi-2763053
} 
will share the results and analysis of the Twitter investigation based on the keywords and years.

\section{1. Keyword of 'Suriyeli Göçmen'}

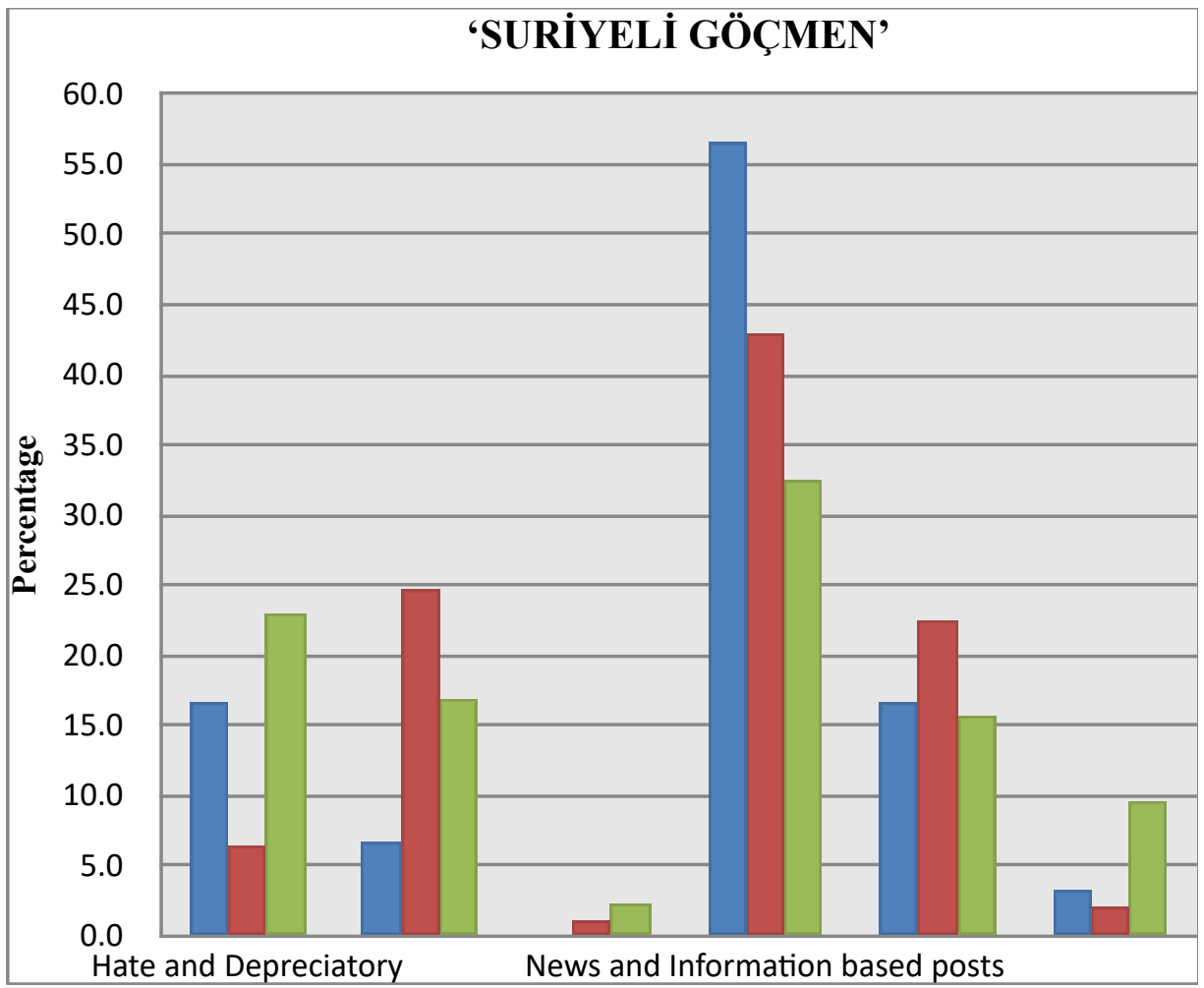

Figure 3: Findings of Twitter Analysis with the Keyword 'Suriyeli Mülteciler'

The vast majority of tweet posts with the words of Syrian immigrants consist of news-related posts. The second most grouped tweets vary by years. Within this framework, 56\% (17) of all tweets containing the keyword Syrian migrants in 2012 are categorized in News and Information Posts. In the upper classification point, $6.7 \%$ of all tweets consisted of tweets with positive content based on tolerance and help basis, while $16.7 \%$ consisted of tweets with negative content. $76.6 \%$ of all tweets can be considered neutral posts that is consist of independent personal opinions, news content and political shares. In 2015, it was seen that the majority of tweet posts (43\%) were again composed of the news content (40/93). The second-highest share (24.7\%) among all twitter posts in 2015 was that of tolerance and humanitarian-based posts (23/93). The main reason for this situation is that photos and stories of the challenges of Syrian refugees on their way to Europe via Turkey are often featured on social media. As it is seen in the figure 3 in above, the intensity of hate-related posts in 2015 was $6.5 \%$ of all Tweet posts made in the relevant year with the Syrian immigrant keyword (6/93). In 2015, the ratio of total positive tweets that contains Syrian migrant keywords was 25.7, while the share of 
negative posts in the same year remained at $6.5 \%$. In contrast to 2012 , there was an increase in tolerance, sensitive and humanitarian posts in 2015.

In this respect, if we compare the hateful and depreciatory posts shared in 2012 and 2015; such shares were observed to decrease compared to all tweets in 2015. On the other side, $16.9 \%$ of all tweets that were posted in 2018 and included 'Syrian immigrant' keywords were categorized in the tolerance and humanitarian posts. Another fact that found within the context of twitter analysis, $22.9 \%$ of all tweets shared in 2018 consist of hateful and depreciatory posts. Compared to 2015, we see that the posts of tolerance have decreased and the posts of hate and depreciatory have increased. Though, the main reasons for the increase in negative contented tweets are; as its shown in the example by Figure 4, idea that Syrians are providing their livelihood by begging instead of working, outbreak of some news about Syrians will be granted citizenship in 2016, signing of the readmission agreement that received a negative reaction from the public with EU in 2016, and Turkish society's start to feel discomfort from the 3.5 million Syrian refugees because their effect on society.

When we look at the content analysis of hateful tweets, almost all of them are posts that compare the problems of Turkish people and Syrian refugees, reflecting them as people who are burden for country and for society, don't work, benefit nobody and are unwelcomed. Though, these posts are trying to make the refugees look inferior at this point. At this point, if we evaluate the data from a structuralist point of view, in line with the conditions of the period, while the wounds of the Van earthquake that occurred in the previous year were still being healed, the government's interest in Syrian refugees and the money it spent were the main driving forces of hate-related posts at this point. If we consider 2015 as an exception in the context of hate speech due to the shaking images $^{49}$ and stories of refugees emerged during their escape to Europe, and due to the humanitarian drama in the living conditions of Syrians in Turkey, we can say that hate speech in general has increased over the years. We can say that tolerance; sensitive and humane posts are on a choppy line. Again, we can say that the calamitous events in 2015 were effective in increasing the number of tolerance-based posts. Furthermore, while tolerance-based posts increased from 2012 through 2015, on the other side, the posts that categorized in the same group declined from 2015 to 2018 , due to the increasing numbers of the Syrian refugees, the uncertainty of their status, and their involvement in criminal incidents.

In general, according to the results to be drawn from this chart, Turkish people shape their feelings and thoughts according to the conditions of the period and share them in this direction. In general context, hate speech and depreciatory posts increased 
by following a wavy line; and also it can be said that tolerance, sensitive and humanitarian posts have followed a fluctuating line, first increased from 2012 to 2015, then decreased from 2015 to 2018. In addition, news contented posts seem so high due to the user profiles of those who shared tweets by using this keyword. Since these profiles are subsidiary accounts of news sites, broadcasting organizations, journalists, or non-association large and small communities that represent an organization. The reason why tweet shares with independent personal opinions remain at low sharing levels in these keyword categories is the not usage of such words by regular people. On the other hand, because the keyword 'Syrians' is generally used by a larger segment of the public, many tweets have been included in the personal independent opinion classification group. Similarly, according to the results of the analysis conducted with the keyword 'Syrians', there were less tweet sharing in the category of news and information posts than in this keyword.

\section{2. Keyword of 'Suriyeli Mülteciler'}

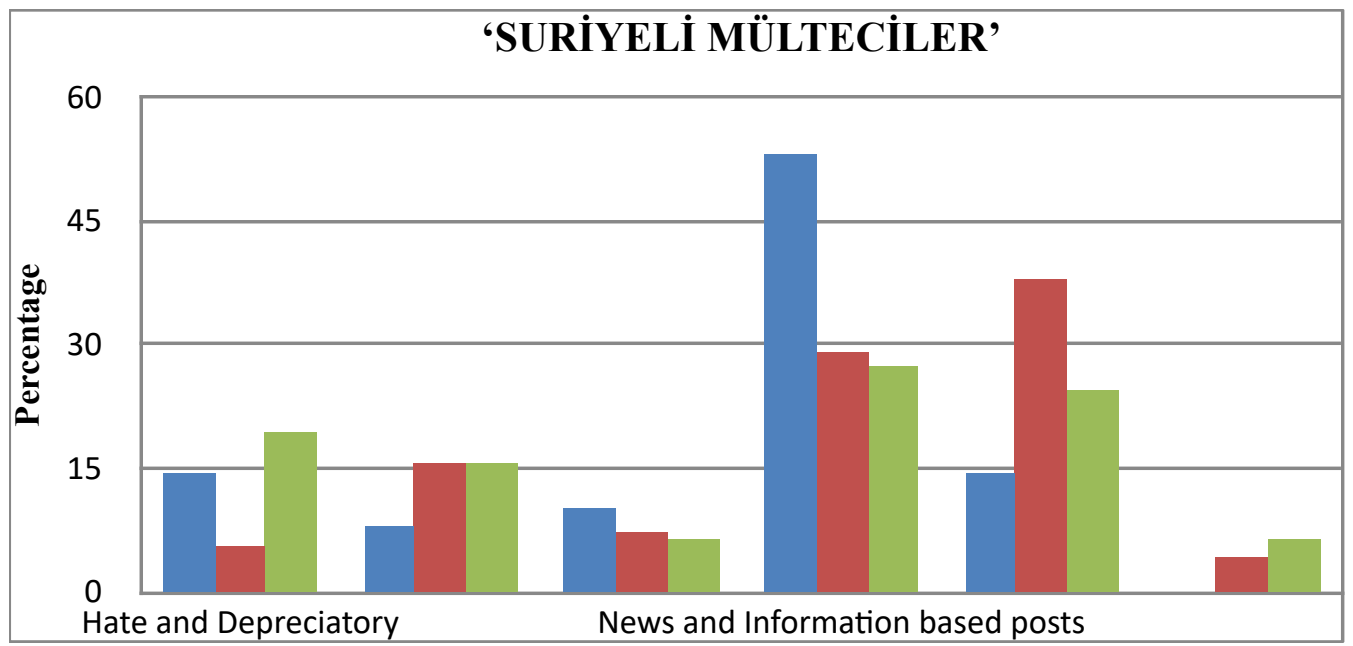

Figure 6: Findings of Twitter Analysis with the Keyword 'Suriyeli Mülteciler'

In the Twitter analysis conducted on the keyword 'Syrian refugees', although a number of different data emerged, data revealed in the same direction as the previous one in general means. In particular, the most striking data are the increase in hate and depreciatory posts, and Tolerance, sensitive and humanitarian posts. Most of the tweets posted in $2012(53.1 \%)$ were categorized in the News and Information posts (26/49). The proportion of positive shares representing the total of Tolerance, Sensitive and Humanitarian posts, and Aid and Social Responsability posts is $18.4 \%$ in 2012 (9/49). Among all tweets that were posted with this keyword in 2012 , negative posts are $14.3 \%$ (7/49).

In 2015, we might see that the highest share of all tweet posts with $38.2 \%$ is personal, independent opinion posts (42/110). According to the results, in 2015, only 
$5.5 \%$ of the tweet posts were contented negatively. In this context, one of the hatecontented tweet posts is shown by figure 7 in below. On the other hand, we can say that $22.8 \%$ of the tweet posts, published in this year, are positively qualified (25/110). At this point, it is obvious that positively qualified posts have increased a little over the years from 2012 to 2015. As mentioned above, the sharing of numerous negative and humanitarian drama images and stories on the migration of Syrian refugees to Europe between 2014 and 2015 has led to an increase in both tolerance and humanitarian sharing as well as assistance and social responsibility sharing.

Afterwards, $27.3 \%$ of all tweets posted in 2018 were classified in the category of News and information Posts (21/77). Another point that needs to be addressed at this point is that information and news content posts have decreased compared to years from 2012 to 2018. In 2018, there has been a remarkable increase in the share of Hate and Depreciatory posts $(\% 19.5)$. This has also led to a reduction in the posts of Aid and Social Responsibility over the years. On the other hand, it is seen that the share of Tolerance and Humanitarian posts this year have not diminished contrary to expectations and calculated as $15.6 \%$ compared to the total posts $(12 / 77)$. The most important elements that are effective in this change are the condemnation of racist approaches, attacks, and propaganda that occurred in Europe towards Syrian refugees and the humanitarian sharing that has been done with this situation's effect.

\section{3. Keyword of 'Suriyeliler'}

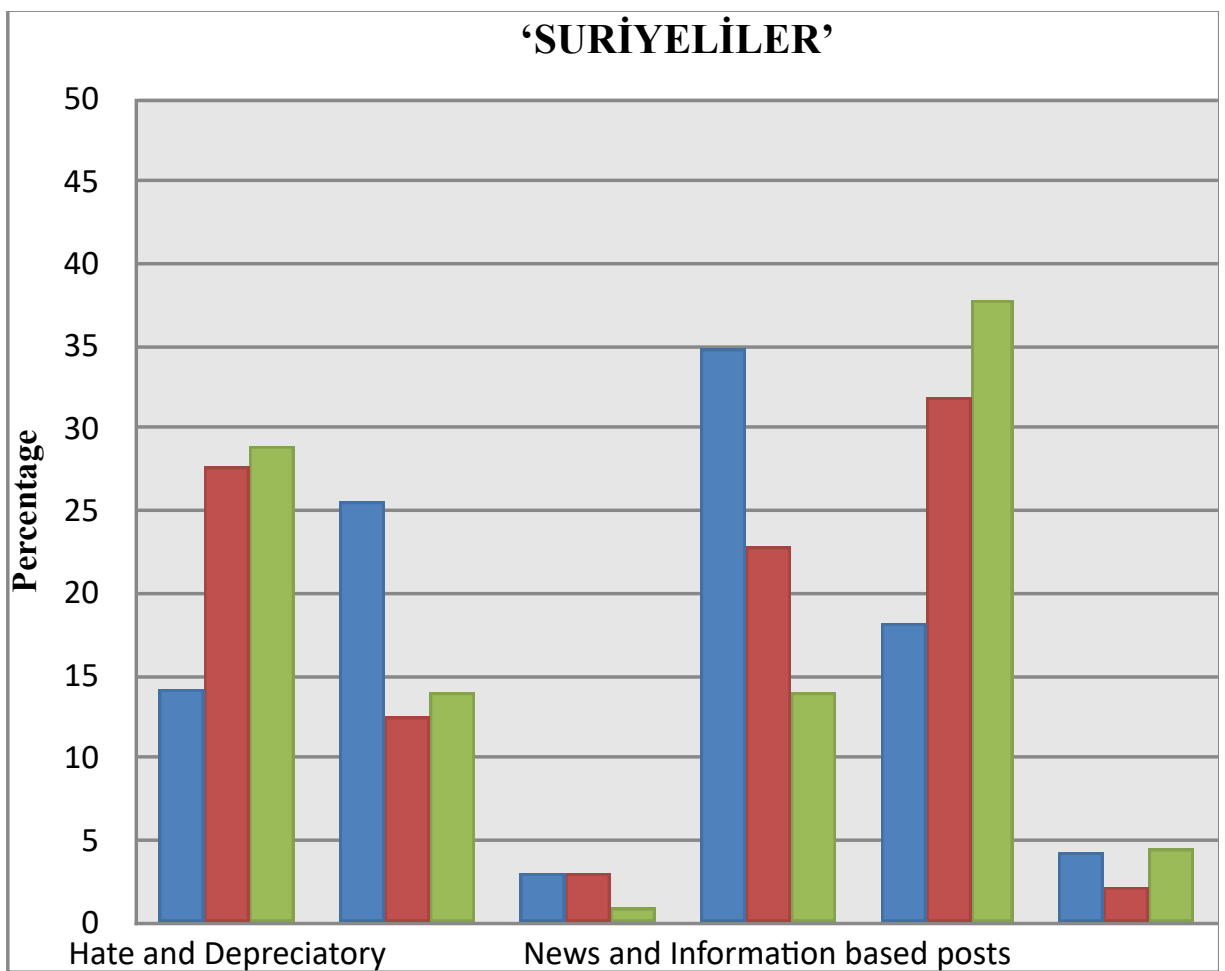

Figure 8: Findings of Twitter Analysis with the Keyword 'Suriyeliler' 
A far greater number of twitter posts have been reached in the analysis via the Syrians keyword. According to the analysis with this keyword, the highest number of shares posted in 2012 with $34.9 \%$ were classified in the category of posts with 'News and information' content (67/192). Then, Tolerance, Sensitive and Humanitarian posts became the category with the highest number of posts with $25.5 \%$ (49/192). The ratio of Hate and Depreciatory Posts to total twitter posts is $14.1 \%$ in $2012(27 / 192)$. The ratio of total positive tweets to total tweets shared this year is $28.6 \%(55 / 192)$. On the other hand, the rate of total negative posts reflected as $14.1 \%$.

When it comes to 2015, it is obvious that the highest proportion of posts are classified in personal independent opinion posts with 31.8\% (202/636). And then, surprisingly, the posts classified in the category of Hate and Depreciatory came in the second with $27.7 \%(176 / 636)$. In fact, these results are consistent with the results of the Transatlantic Trends 2014 survey. According to this study, the proportion of people who identify immigration as a problem in Turkey is increased from $29 \%$ in 2013 to $75 \%$ in 2014. In the Twitter analysis section, we see that Tolerance, Sensitive and Humanitarian sharings posted in 2015 remains at a rate of $12 \%(80 / 636)$.

In 2018 , the largest number of tweets $(37.7 \%)$ are classified in the category of Personal Independent Opinion Posts. Then it comes across as the second most tweetcontaining category, with $28.9 \%$ of Hate and Depreciatory Posts. In this direction, two intances of the Hate and Depreciatory posts published with 'Suriyeliler' keyword in 2018 is shown by figure 9 and figure 10 below. While $13.9 \%$ of tweets posted this year classified in the category of Tolerance, Sensitive, and Humanitarian Posts, therefore, in total, $14.9 \%$ tweets posted with positive attitudes.

\section{CONCLUSION}

According to all these results, the research question has been largely answered within the scope of Twitter analysis and it is observed that Turkish people's tolerance towards Syrian refugees has been decreased. This research question was supported by the results of the literature review. The results of the studies in the literature have been used to determine the factors that are effective in this decline. According to the results of the analysis with this keyword, the Turkish community did not show any negative attitude towards the Syrian refugees in the early years, but on the contrary, the Turkish community helped the Syrians in many ways by offering them hospitality. However, due to the unexpected increase in the number of Syrian refugees in the following years and the increasing irregularity, uncertainty and other problems in proportion to this number, the Turkish people started to take a negative attitude towards refugees. Especially by 2018 , the results show that the majority of Turkish people do not want 
refugees, and refugees should return to their countries, or they should live in buffer zones to be created at the border. Another discourse revealed from the analysis is that if public expenditure were spent on the Turkish people, the economic problems experienced in 2018 could never have occurred.

The outputs of the analysis reveal the main reasons for the decline in tolerance of Turkish people. Those reasons can be sorted as prolongation of Syrian refugees' stay; the fact that the status and situation of the Syrian refugees is not clear; the idea that Syrian refugees receive more value and help than the Turkish people in need; rumor that Syrian refugees will be granted citizenship and will be given the right to vote in elections; the opinion that Syrian refugees are causing the Turkish people's economic situation to worsen; inability to integrate Syrian refugees into Turkish social and cultural values; the idea that crime rates and criminal cases increased with the arrival of Syrian refugees, and see the Syrian refugees as a burden to Turkish society.

The most critical advice that can be given at this point is to approach Syrian refugees without ignoring the fact that they have fled their homes, workplaces, schools, social circles and, most importantly, their country of nationality and have taken refuge in the state of the Republic of Turkey because of the brutal war conditions. In other words, if Turkish society tries to understand the mental and psychological situation and living conditions of Syrians and approach them accordingly, it will accelerate their integration and social inclusion. On the other hand, it would be more appropriate for our managers to produce more constructive solutions and policies concerning the need in terms of the mental and moral health of the two communities.

\section{ACKNOWLEDGEMENT}

This research received no specific grant from any funding agency in the public, commercial, or not-for-profit sectors.

\section{KAYNAKÇA}

Agamben, Georgio. (2001). Kutsal İnsan: Egemen İktidar ve Çılak Hayat, Ayrıntı Yayınları.

Aslan, Ömer. (2001). Hoşgörü ve Tolerans Kavramlarına Etimolojik Açıdan Analitik Bir Yaklaşım. Cumhuriyet Üniversitesi İlahiyat Fakültesi Dergisi 5(2), 357-380.

Aydın, Mustafa, et al. Türkiye Sosyal-Siyasal Eğilimler Araştırması 2018, Kadir Has Üniversitesi Türkiye Araştırmaları Merkezi, 2019. https://www.khas.edu.tr/uploads/ turkiye-sosyal-siyasal-egilimler-arastirmasi-2018.pdf 
Böke, Kaan. (2014). Sosyal Bilimlerde Araştırma Yöntemleri.(4. Baskı). İstanbul: Alfa Yayınları.

Cohen, Andrew Jason. (2004). What toleration is. The Journal of Ethics,115, 68-95.

Çalık, Muammer. et al. (2008). Trends in Turkish Science Education. Essays in Education 24/1, 23-45.

Çayır, Kenan. (2010). Ayrımcılığın sosyolojisi ve Türkiye toplumu. Çavdar, Ayşe. And Yıldırım, Aylin Brigitte (Ed). Nefret Suçları ve Nefret Söylemi içinde (p. 45-54). İstanbul: Uluslararası Hrant Dink Vakfı Yayınları.

Çiftçi, Hasan. (2018). Türkiye Cumhuriyeti Vatandaşlarının Suriyeli Sığınmacılara Yönelik Tutum, Algı ve Empatik Eğilimlerinin Analizi. Itobiad: Journal of the Human \& Social Science Researches, 7(3), 2232-2256.

Çimen, Latife Kabaklı \& Quadir, Seher Ersoy. (2018). Üniversite öğrencilerinin Suriyeli sığınmacılarla ilgili tutumlarının sivil katılımları bağlamında incelenmesi. İnsan ve Toplum Bilimleri Araştırmaları Dergisi, 7(2), 1251-1273.

Çolak, Filiz. (2013). Bulgaristan Türklerinin Türkiye’ye Göç Hareketi. Tarih Okulu Dergisi, (14), 113-145.

Demirbaş, Timur. (2017). Nefret Söylemi ve Nefret Suçları. Dokuz Eylül Üniversitesi Hukuk Fakültesi Dergisi 19(3). 2693-2701.

Digitalage, “Twitter'1n 2014 Türkiye Karnesi”, Access: 13.11.2020, https:// digitalage.com.tr/twitterin-2014-turkiye-karnesi/

Dinçer, Osman Bahadır. et al. (2013). Suriyeli Mülteciler ve Türkiye: Sonu Gelmeyen Misafirlik. International Strategic Research Organization and Brookings Enstitüsü, Karınca Ajans Yayıncılık Matbaacılık: Ankara.

Düşündere, Ayşegül Taşöz \& Çilingir, Yasemin Satır. (2017). Göçmenlere Karşı Kötümserlik Artıyor mu. Türkiye Ekonomi Politikaları Araştırma Vakfı. Erişim, 2 Şubat 2020.

Erdoğan, Murat. (2014). Türkiye’deki Suriyeliler: Toplumsal Kabul Ve Uyum Araştırması. Hacettepe Üniversitesi Göç ve Siyaset Araştırmaları Merkezi, Ankara.

Erdoğan, Murat. (2018). Suriyeliler Barometresi: Suriyelilerle Uyum İçinde Yaşamın Çerçevesi. İstanbul Bilgi Üniversitesi Yayınları, İstanbul. 
Erdoğan, Murat. (2019). Türkiyedeki Suriyeli Mülteciler. Konrad Adenauer Stiftung, İstanbul.

Erkal, Mustafa. (1992). Sosyal bütünleşmede hoşgörünün yeri. Erdem Dergisi, 8: $151-158$.

Foreigners And International Protection Law (2013, March 11). The Official Journal (No: 28615). https://www.mevzuat.gov.tr/MevzuatMetin/1.5.6458.pdf

General Assembly of the United Nations Fifth Committee, (1950). Draft convention relating to the status of refugees.

GMF, The German Marshall Fund of United States. Transatlantic Trends Key Findings 2013. New York: The German Marshall Fund of United States. 2013. https:// w w w. $\mathrm{t}$ e p a v. o r g.t r / u p 1 o a d / f i 1 e s / h a b e r / 1379593690-3.Transatlantic_Trends_Key_Findings_2013.pdf

GMF, The German Marshall Fund of United States. Transatlantic Trends: Mobility, Migration And Integration. New York: The German Marshall Fund of United States. $\quad 2014$. https://gfmd.org/files/documents/ gfmd turkey2014-2015 tm2 contribution_german_marshall_fund.pdf

Goupy, Marie. (2018). The state of exception theory of Carl Schmitt and the ambivalent criticism of liberalism. Zeitschrift für Politikwissenschaft, 28(4), 395-408.

Gök, Ömer Faruk. (2017). Schmitt ve Benjamin: İki Olağanüstü Hâl. Hukuk Kuramı Dergisi, 4(3). 1-13.

Güçer, Mehmet, et al. (2013). Sinırlar Arasında Yaşam Savaşı, Suriyeli Mülteciler: Alan Araştırması: International Strategic Research Organization (USAK).

Karaman, Hasan \& Işıklı, Şevki. (2016). Twitter'daki Dini ve Etnik Temelli Nefret Söylemlerinin Analizi. AJIT-E: Online Academic Journal of Information Technology, 7(25). 137-152.

Kaypak, Şafak. (2016) Demokrasi Kültürü ve Hoşgörü: Hatay Örneğinde. 2. Uluslararası Çin'den Adriyatik'e Sosyal Bilimler Kongresi (5-7 Mayıs 2016) Kitabı: 147-160.

Kirisçi, Kemal. (1996). Refugees of Turkish origin: 'Coerced immigrants' to Turkey since 1945. International Migration (Geneva, Switzerland), 34(3), 385-412.

Kirişci, Kemal. (2016). Turkey's Role in the Syrian Refugee Crisis: An Interview with Kemal Kirişci. Georgetown Journal of International Affairs: 80-85. 
Kirişçi, Kemal. (2014). Misafirliğin Ötesine Geçerken Türkiye’nin “Suriyeli Mülteciler” Sınavı Raporu. Uluslararası Stratejik Araştırmalar Kurumu \& Brookings Enstitüsü.

Kurt, Gözde. (2019). Yeni Medyada Nefret Söylemi: Youtube'da Suriyeli Mültecilere Karşı Üretilen Nefret Söylemi Üzerine Bir Araştırma. The Journal of International Lingual Social and Educational Sciences, (5): 1-20.

Milliyet, “Türkiye'nin Sosyal Medya Karnesi Açıklandı”. Access: 19.10.2018 http://www.milliyet.com.tr/teknoloji/turkiyenin-sosyal-medya-karnesiaciklandi-2763053

Öztekin, Hülya. (2015). Yeni Medyada Nefret Söylemi: Ekşi Sözlük Örneği. Journal of International Social Research 8(38), 925-936.

Pınar, Mehmet. (2017). 1950-1951 Bulgaristan'dan Türkiye'ye Göçler ve Demokrat Parti'nin Göçmen Politikası. Atatürk Araştırma Merkezi Dergisi, 30(89), 61-94.

Quadir, Seher Ersoy \& Çimen, Latife Kabaklı. (2018). Türk Vatandaşlarının Suriyeli Sığınmacılarla İlgili Görüşleri (Konya İli Örneği). Third Sector Social Economic Review, 53(2), 327-345.

Regulation on Work Permits of Foreigners Provided Provisional Protection (2016, 15 January). The Official Journal (No: 29594). https://www.mevzuat.gov.tr/ MevzuatMetin/3.5.20168375.pdf

Sabah, "Dünyada 3 Milyar 190 Bin Kişi Sosyal Medya Kullanıyor”. Access: 19.3.2018. https://www.sabah.com.tr/teknoloji/2018/03/19/dunyada-3-milyar-190-binkisi-sosyal-medya-kullaniyor

Sağlam, Mehmet. (1996). Geleneksel Türk Hoşgörüsü. Erdem Dergisi 8: 359-364.

Sarı, Arzu Çalışkan \& Alkar, Özden Yalçınkaya. (2018). The Attitudes Towards Syrians Living in Turkey: A Scale Development. Göç Araştırmaları Dergisi, 4(2), $10-36$.

Suri, Harsh \& Clarke, David. (2009). Advancements in Research Synthesis Methods: From A Methodologically Inclusive Perspective. Review of Educational Research 79(1), 395-430. 
Şit, Ahmet Can, "Türkiye Saniyede 20 Tweet Atıyor", Webrazzi, Access: 12.12.2020. https://webrazzi.com/2012/03/14/monitera-turkiye-tweet-istatistikwebrazzi-dijital12/

Tamer, Mine Gözübüyük. (2016). Trabzon Kamuoyunun Geçici Koruma Kapsamındaki Suriyelilere Bakış Açısı. Karadeniz Araştırmaları Enstitüsü Dergisi (2): 180-211.

Temporary Protection Regulation (2014, 22 October) The Official Journal (No: 29153) https://www.resmigazete.gov.tr/eskiler/2014/10/20141022-15-1.pdf

UNHCR, United Nations High Commissioner for Refugees, "What is A Refugee". Access: 20.11.2020. https://www.unhcr.org/what-is-a-refugee.html

Ünal, Serdar. (2014). Türkiye'nin Beklenmedik Konukları: 'Öteki’ Bağlamında Yabanc1 Göçmen ve Mülteci Deneyimi. Zeitschrift für die Welt der Türken/Journal of World of Turks (6): 65-89.

Vardal, Zeynep Burcu. (2015). Nefret Söylemi ve Yeni Medya. Maltepe Üniversitesi İletişim Fakültesi Dergisi (2): 132-156.

We Are Social. Digital in 2018 in Western Asia. Access: 08.02.2020. https:// datareportal.com/reports/digital-2018-turkey

Yıldırımalp, Sinem \& Cemal, İyem. (2017). Suriyeli Sığınmacıların Toplumsal Kabul ve Uyum Sürecine İlişkin Bir Araştırma. Bilgi Sosyal Bilimler Dergisi (2), 107-126. 